See discussions, stats, and author profiles for this publication at: https://www.researchgate.net/publication/340479041

\title{
Etablishing the first continuous Holocene tephrostratigraphy on Kerguelen Archipelago, subantarctic Indian Oean
}

Conference Paper · April 2020

DOI: 10.5194/egusphere-egu2020-5782

\section{CITATIONS}

20 authors, including:

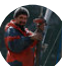

Fabien Arnaud

Université Savoie Mont Blanc

380 PUBLICATIONS 4,863 CITATIONS

SEE PROFILE

Bertrand N. Moine

Université Clermont Auvergne

94 PUBLICATIONS 1,030 CITATIONS

SEE PROFILE
Pierre Sabatier

Université Savoie Mont Blanc

207 PUBLICATIONS 2,235 CITATIONS

SEE PROFILE

Anne-Lise Develle

Université Savoie Mont Blanc

115 PUBLICATIONS 745 CITATIONS

SEE PROFILE

Some of the authors of this publication are also working on these related projects:

Project $\quad$ Recycled Archean oceanic crust preserved in the subcratonic mantle View project

Project Long-term dynamics of microbial eukaryotic communities from lakes View project 
EGU2020-5782

https://doi.org/10.5194/egusphere-egu2020-5782

EGU General Assembly 2020

(c) Author(s) 2020. This work is distributed under

the Creative Commons Attribution 4.0 License.

\section{Etablishing the first continuous Holocene tephrostratigraphy on Kerguelen Archipelago, subantarctic Indian Oean}

Fabien Arnaud ${ }^{1}$, Pierre Sabatier ${ }^{1}$, Anouk Leloup ${ }^{1}$, Aymerick Servettaz ${ }^{1,2}$, Bertrand Moine ${ }^{3}$, AnneLise Develle ${ }^{1}$, Stéphane Guédron ${ }^{4}$, Vincent Perrot ${ }^{4}$, Jérôme Poulenard ${ }^{1}$, Bernard Fanget ${ }^{1}$, Emmanuel Malet ${ }^{1}$, Eivind Støren ${ }^{5}$, Jean-Louis Reyss ${ }^{1}$, Nicolas Le Viavan ${ }^{6}$, Katrien Heirman ${ }^{7}$, Marc De Batist $^{7}$, Elisabeth Michel ${ }^{2}$, Jacques-Louis de Beaulieu ${ }^{8}$, Nathalie Vanderputten ${ }^{2}$, and Jostein Bakke ${ }^{5}$ ${ }^{1}$ Environment Dynamics and Territories of the Mountains (EDYTEM), Université Savoie Mont-Blanc, CNRS, 73000 Chambéry, France

${ }^{2}$ Laboratoire des Sciences du Climat et de l'Environnement (LSCE), CEA, CNRS, 91 Gif-sur-Yvette, France

${ }^{3}$ Laboratoire Magmas et Volcans, Université Jean Monnet, CNRS, 42023 Saint-Etienne France

${ }^{4}$ Institut des Sciences de la Terre (ISTerre), Université Grenoble Alpes, CNRS, Grenoble, France

${ }^{5}$ Department of Earth Science and Bjerknes Centre for Climate Research, University of Bergen, Allégaten 41, 5007 Bergen, Norway

${ }^{6}$ Institut Paul-Emile Victor (IPEV), 29280, Plouzané, France

${ }^{7}$ Renard Centre of Marine Geology, Department of Geology and Soil Sciences, Ghent University, Krijgslaan 281 S8, B-9000 Ghent, Belgium

${ }^{8}$ Institut Méditerranéen de Biodiversité et d'Ecologie marine et occidentale (IMBE), Aix-Marseille Université, CNRS, 13545 Aix en Provence, France

Here we present the first Holocene-long continuous chronology of volcanic eruptions on Kerguelen archipelago, where no evidence of Holocene volcanic activity has been published so far. Our chronicle is based upon sedimentological, chronological and geochemical data form two sediment cores, taken in two different depocenters of a large lake, Lake Armor, located ca. $70 \mathrm{~km}$ away from the archipelago's potentially active volcanic area. This allowed us to confidently attribute the origin of pumice-rich or ash-rich layers to contemporaneous volcanic eruptions. Altogther eight main eruptions, as well as three secondary ones, were here documented and dated, among which the youngest occurred during the Middle Age, between 890 and 980 AD. The oldest eruption is also by far the strongest one and deposited more than $1.2 \mathrm{~m}$ of up-to $3 \mathrm{~cm}$ large pumices, $70 \mathrm{~km}$ away from the volcanic edifice. It occurred at the very beginnning of the Holocene (11 ka cal. BP), suggesting a climatic control after glacial retreat upon volcanic activity. Additionnal evidences from lake sediment and geological outcrops, both close to Lake Armor and in remote areas over Kerguelen mainland, open the future possibility of a better reconstruction of major eruptions deposit spreading and thus an assessment of their intensity. This established chronostratigraphy will be useful to synchronise paleoenvironment record at least at the scale of the archipelago as well as in surrounding marine areas where Holocene climate reconstructions are particularly sparse. 